\title{
Clinical significance of galectin-7 in vulvar squamous cell carcinoma
}

\author{
YING JIANG $^{1}$, RUOYANG TIAN ${ }^{1}$, SHUANG YU ${ }^{2}$, YI ZHAO ${ }^{1}$, YANG CHEN ${ }^{2}$, HUI LI $^{1}$, YING QIAO ${ }^{2}$ and XIN WU ${ }^{1}$ \\ ${ }^{1}$ Department of Obstetrics and Gynecology; ${ }^{2}$ Central Laboratory, First Affiliated Hospital of China Medical University, \\ Shenyang, Liaoning 110001, P.R. China
}

Received October 30, 2014; Accepted August 20, 2015

DOI: $10.3892 / \mathrm{ol} .2015 .3826$

\begin{abstract}
The present study reports the role of galectin-7 (Gal-7) expression in vulvar squamous cell carcinoma (VSCC) and its correlation with clinicopathological variables. Gal-7 expression was immunohistochemically detected in the paraffin-embedded sections of 20 normal vulvar biopsy samples and 50 VSCC specimens. Expression was also detected in 10 normal vulvar biopsy samples and 10 VSCC specimens by western blotting. In addition, the methylation status of the promoter of the Gal-7 gene was determined in $30 \mathrm{VSCC}$ specimens and 20 samples of normal vulvar tissue by methylation-specific polymerase chain reaction. Gal-7 expression was found to be significantly downregulated in the VSCC tissues compared with the normal vulvar tissues $(\mathrm{P}<0.05)$. Downregulation of Gal-7 was correlated with advanced clinical stage, poor tumor differentiation and regional lymph node metastasis $(\mathrm{P}<0.05)$. Furthermore, methylation of the Gal-7 gene promoter was significantly reduced in the vulvar normal tissues compared with the VSCC tissues $(\mathrm{P}=0.023)$, while increased Gal-7 promoter methylation was correlated with advanced clinical stage, poor tumor differentiation and regional lymph node metastasis $(\mathrm{P}<0.05)$. There was no association between patient age and Gal-7 promoter methylation. Together, these results suggested that Gal-7 has a negative impact in patients with VSCC, with malignant potential correlating with Gal-7 promoter methylation.
\end{abstract}

\section{Introduction}

Vulvar carcinoma accounts for 3-5\% of all female genital cancers. Previously considered as a disease found in elderly women, it is now recognized that the incidence among younger women $(<50$ years old) is increasing. Radical vulvectomy

Correspondence to: Professor Xin Wu, Department of Obstetrics and Gynecology, First Affiliated Hospital of China Medical University, 155 Nanjing Bei Street, Shenyang, Liaoning 110001, P.R. China

E-mail: xinwu.1964@aliyun.com

Key words: vulvar squamous cell carcinoma, galectin-7, methylation, immunohistochemistry, western blotting with bilateral inguinofemoral lymphadenectomy has been the standard treatment for the majority of patients, but is associated with a high risk of post-operative complications (1). Individualized therapy incurs fewer complications and can improve outcome; the identification of novel biomarkers for vulvar carcinoma progression will greatly aid the development of such individualized therapies.

Galectins constitute a family of lectins defined by shared consensus amino acid sequences and affinity for $\beta$-galactose-containing oligosaccharides. To date, 14 mammalian galectins have been identified and several have been shown to exhibit important functions in physiological processes such as embryonic development, apoptosis, wound healing, cell migration, intercellular adhesion and immune responses (2). Galectins have also been indicated to be involved in a number of pathological conditions, including infectious diseases and cancer. Magnaldo et al (3) initially described galectin-7 (Gal-7) as a marker of differentiation in stratified epithelia. Gal-7 exhibits a wide range of biological functions, including the regulation of cell growth, adhesion and apoptosis (4). There have been a number of studies showing that the expression of Gal-7 is altered in tumors, with upregulation and downregulation each being described in different tumor types $(3,5-8)$. However, the precise role of Gal-7 in cancer development remains under debate.

The expression of Gal-7 in VSCC has not been previously reported and its clinical significance in patients with VSCC remains unknown. Therefore, the present study investigated whether abnormal Gal-7 expression is associated with VSCC malignant progression using western blotting and immunohistochemistry (IHC), and also assessed the degree of methylation at the Gal-7 (LGALS7) gene promoter using methylation-specific polymerase chain reaction (MSP) to define the potential mechanisms of abnormal Gal-7 expression.

\section{Materials and methods}

Sample collection and preparation. Tissue specimens were obtained from 50 patients with VSCC who had undergone surgery in the Department of Gynecology of The First Affiliated Hospital of China Medical University (Shenyang, Liaoning, China) between 1998 and 2011. All patients underwent curative resection, but were not treated with neoadjuvant chemotherapy or radiotherapy. Immediately after surgery, the specimen was divided into two sections: The first was stored 
at $-80^{\circ} \mathrm{C}$ and the second section was fixed in formalin. Normal vulvar tissue specimens were also obtained from 20 patients undergoing vulvar repair procedures. Tissue specimens were obtained after obtaining informed consent from all patients and the study was approved by the Research Ethical Committee of The First Affiliated Hospital of China Medical University.

Patient and tissue characteristics. The 50 patients with VSCC (mean age, 55.7 \pm 3.9 years; range, 33-73 years) included 15 with Federation of International Gynecologists and Obstetricians (1988) stage I disease, 22 with stage II disease and 13 with stage III disease. In terms of histological grade, 29 specimens were well-differentiated, 16 were moderately-differentiated and 5 were poorly-differentiated. There were 15 patients with lymphatic node metastasis across all groups.

Western blot analysis. In total, 10 paired VSCC and corresponding age-matched normal vulvar samples were selected for western blot analysis. Equal quantities of protein from each sample were separated by $15 \%$ SDS-PAGE and then transferred to polyvinylidene fluoride membranes (Bio-Rad Laboratories, Inc., Hercules, CA, USA). The membranes were blocked in 5\% skimmed milk in Tris-buffered saline with Tween-20 buffer [20 mM Tris (pH 7.6), $137 \mathrm{mM} \mathrm{NaCl}$ and $0.05 \%$ Tween-20) at room temperature for $2 \mathrm{~h}$, prior to incubation with the primary antibodies for $2 \mathrm{~h}$ at room temperature. The following primary antibodies were used: rabbit monoclonal anti-Gal-7 (1:1,000; ab108623; Abcam, Cambridge, UK) and mouse monoclonal anti- $\beta$-actin (1:1,000; Santa Cruz Biotechnology Inc., Dallas, TX, USA). Mouse anti- $\beta$-actin $(1: 1,000$, Santa Cruz Biotechnology) was used as a loading control. The membranes were then incubated with their corresponding anti-mouse or anti-rabbit secondary antibody for $1 \mathrm{~h}$ at room temperature. The protein bands were visualized using an electrochemiluminescence detection kit (Beyotime Institute of Biotechnology, Shanghai, China), and the densities of the protein bands were determined by Quantity One v.4.62 software (Bio-Rad Laboratories Inc.). Each analysis was performed at least three times.

$I H C$. Formalin-fixed paraffin embedded sections (4- $\mu \mathrm{m}$ thick) from the 50 cases of VSCC and the 20 samples of normal vulvar tissue were analyzed by IHC. The sections were stained according to the streptavidin-biotin-immunoperoxidase method described by Ohno et al (9), in 1998. Briefly, each section was deparaffinized with xylene, rehydrated and washed with phosphate-buffered saline (PBS). Antigen retrieval was performed by autoclaving the sections in citrate buffer $[0.016 \mathrm{M}$ citric acid and $0.084 \mathrm{M}$ sodium citrate $\left(\mathrm{pH} \mathrm{6.0)]} \mathrm{at} 120^{\circ} \mathrm{C}\right.$ for $2 \mathrm{~min}$. The sections were allowed to cool to room temperature and then washed three times for $5 \mathrm{~min}$ in PBS. The sections were incubated in $0.3 \%$ hydrogen peroxide in absolute methanol for $15 \mathrm{~min}$ to suppress endogenous peroxidase activity; this was followed by incubation with $1 \%$ bovine serum albumin for $15 \mathrm{~min}$ to prevent non-specific binding. The sections were incubated with the same primary antibodies that had been used for western blotting (Gal-7; 1:800) at $4^{\circ} \mathrm{C}$ overnight. Subsequent to being washed three times for $5 \mathrm{~min}$ in PBS, the sections were incubated with their corresponding secondary antibodies, as for the western blotting. The samples were then labeled with streptavidin peroxidase for $15 \mathrm{~min}$, treated with diaminobenzidine as a chromogen for $5 \mathrm{~min}$ and counterstained with Mayer's hematoxylin. The sections were washed with PBS between each step of the procedure. Negative controls were prepared by processing different sections following the same procedure, but omitting the primary antibodies. Images of 5 randomly selected fields from non-necrotic areas in the VSCC sections and from epidermal cell layers, including a region of the dermis area in the normal vulvar tissues, were captured and analyzed using an image analysis system (MetaMorph, Universal Imaging Corporation, Dowington, PA, USA) and an Olympus digital camera (DP10/Bx41; Olympus Corp., Tokyo, Japan) following the manufacturer's instructions. Analysis was performed after hue-saturation-intensity transformation and color-deconvolution. After evaluating several fields on positive control slides, the intensity threshold for the immunostaining (brown) was set. The mean integrated optical density (OD) was evaluated for each image and the average change in OD between the positive areas in the VSCC tissue and normal vulvar tissue was calculated.

DNA preparation and DNA modification (bisulfite treatment). A total of 30 paraffin-embedded VSCC tissues and 20 paraffin-embedded normal vulvar tissues were retrieved using xylene and alcohol, and isolated using a DNA extraction kit (E.Z.N.A. ${ }^{\circledR}$ Tissue DNA kit; Omega Nio-Tek Inc., Norcross, GA, USA).

DNA modification with sodium bisulfite causes unmethylated cytosine bases to convert to uracil, while methylated cytosine is resistant to conversion and remains unchanged (10). Therefore, following bisulfite treatment, methylated alleles will have a different sequence compared with unmethylated alleles. This can be used to design allele-specific PCR primers to permit MSP. Genomic DNA ( $2 \mu \mathrm{g}$ ) was first denatured by heating to $97^{\circ} \mathrm{C}$ for $10 \mathrm{~min}$, followed by chilling on ice at $0^{\circ} \mathrm{C}$ for $5 \mathrm{~min}$, and was then incubated for $20 \mathrm{~min}$ at $48^{\circ} \mathrm{C}$ with $3 \mathrm{M}$ $\mathrm{NaOH}(2 \mu \mathrm{l})$. Bisulfite solution (2.5 M sodium metabisulfite and $125 \mathrm{mM}$ hydroquinone) was added and incubated for $12 \mathrm{~h}$ at $48^{\circ} \mathrm{C}$ in the dark. The bisulfite-modified DNA was then purified using Wizard DNA purification resin (DNA Cleanup kit; Promega Corporation, Madison, WI, USA) according to the manufacturer's instructions. Modified DNA was treated with $3 \mathrm{M} \mathrm{NaOH}(5 \mu \mathrm{l})$ in $37^{\circ} \mathrm{C}$ for $10 \mathrm{~min}$ and precipitated with ammonium acetate $5 \mathrm{M}(75 \mu \mathrm{l}), 2.5$ volumes $100 \%$ ethanol and $2 \mu 1$ glycogen ( $20 \mathrm{mg} / \mathrm{ml}$; Sigma-Aldrich, St. Louis, MO, USA) and dissolved in $20 \mu 15 \mathrm{mM}$ Tris (pH 8.0).

MSP. Since members of the galectin family have been shown to be regulated by DNA methylation, the present study investigated the methylation status of $\mathrm{CpGs}$ located in the promoter region (from $-200 \mathrm{bp}$ upstream to $-30 \mathrm{bp}$ from the ATG start codon) of the human Gal-7 gene in VSCC by MSP $(11,12)$. The modified DNA served as a template using primers specific for either the methylated or bisulfite-modified unmethylated sequence. The methylation specific primers were as follows: Forward, 5'-GTTTTTAAGAAGAGGTGTTATTTTCG-3' and reverse, 5'-AACCTACTAAAAACCTTAAATAAAAACA-3'. The unmethylated DNA specific primers were as follows: Forward, 5'-AGTTTTTAAGAAGAGGTGTTATTTTTG-3' and reverse, 5'-AACCTACTAAAAACCTTAAATAAAAACA-3'. The PCR mixture contained 2X GC buffer 
Table I. Galectin-7 expression in VSCC and vulvar normal tissues based on immunohistochemistry.

\begin{tabular}{lcccc}
\hline Group & $\mathrm{n}$ & Mean IOD & $\mathrm{t}$ & P-value \\
\hline VSCC & 50 & $0.3380 \pm 0.0118$ & & \\
Vulvar normal tissue & 20 & $0.3441 \pm 0.0177$ & 2.26 & 0.026
\end{tabular}

IOD, integrated optical density; VSCC, vulvar squamous cell carcinoma.

Table II. Correlation between the expression of immunoreactivity to Gal-7 and clinicopathological features in 50 patients with vulvar squamous cell carcinoma.

\begin{tabular}{lccc}
\hline & & \multicolumn{2}{c}{ Gal-7 } \\
\cline { 3 - 4 } $\begin{array}{l}\text { Clinicopathological } \\
\text { features }\end{array}$ & $\mathrm{n}$ & Mean IOD & P-value \\
\hline $\begin{array}{l}\text { Age, years } \\
\quad 45\end{array}$ & 13 & $0.3364 \pm 0.0095$ & 0.469 \\
$\quad>45$ & 37 & $0.3386 \pm 0.0125$ & \\
$\begin{array}{l}\text { Lymph node metastasis } \\
\quad \text { Negative }\end{array}$ & 35 & $0.3399 \pm 0.0069$ & 0.048 \\
$\quad \begin{array}{l}\text { Positive } \\
\text { Clinical stage }\end{array}$ & 15 & $0.3327 \pm 0.0083$ & \\
$\begin{array}{l}\text { I } \\
\text { II and III }\end{array}$ & 15 & $0.3409 \pm 0.0104$ & 0.022 \\
$\begin{array}{l}\text { Histological type } \\
\quad \text { Well-differentiated }\end{array}$ & 35 & $0.3341 \pm 0.0064$ & \\
$\begin{array}{l}\text { Moderately- and } \\
\text { poorly-differentiated }\end{array}$ & 29 & $0.3422 \pm 0.0109$ & 0.040 \\
\hline
\end{tabular}

Gal-7, Galectin-7; IOD, integrated optical density.

(Takara Biotechnology Co., Ltd., Dalian, China) with $4 \mathrm{mmol} / \mathrm{l}$ $\mathrm{MgCl}_{2}, 10 \mu \mathrm{mol} / 1$ of each primer, $6.25 \mathrm{mmol} / 1 \mathrm{dNTPs}$ and 1.5 unit LA Taq polymerase (Takara Biotechnology Co., Ltd.). The PCR amplification of the modified DNA samples consisted of one cycle of $94^{\circ} \mathrm{C}$ for $10 \mathrm{~min}$, followed by 40 cycles of $94^{\circ} \mathrm{C}$ for $30 \mathrm{sec}, 53^{\circ} \mathrm{C}$ for $30 \mathrm{sec}$ and $72^{\circ} \mathrm{C}$ for $1 \mathrm{~min}$, and then one cycle of $72^{\circ} \mathrm{C}$ for $10 \mathrm{~min}$. Human placental DNA was used as a positive control for unmethylated DNA. In order to make a positive control for methylated DNA, DNA from human placental tissue was treated with M.SssI CpG methyltransferase (New England BioLabs, Ipswich, MA, USA) prior to bisulfite treatment. The PCR generated a 146-bp methylated product and a 147-bp unmethylated product. Amplified PCR product $(6 \mu \mathrm{l})$ were loaded onto $3 \%$ agarose gels, stained with ethidium bromide and directly visualized under ultraviolet illumination.

Statistical analyses. Statistical analyses of western blotting, IHC and MSP data were performed using SPSS v.13.0 software (SPSS Inc., Chicago, IL, USA). The statistical differences between groups in western blotting were compared using a paired sample t-test. Student's t-test was used to compare statistical differences
A

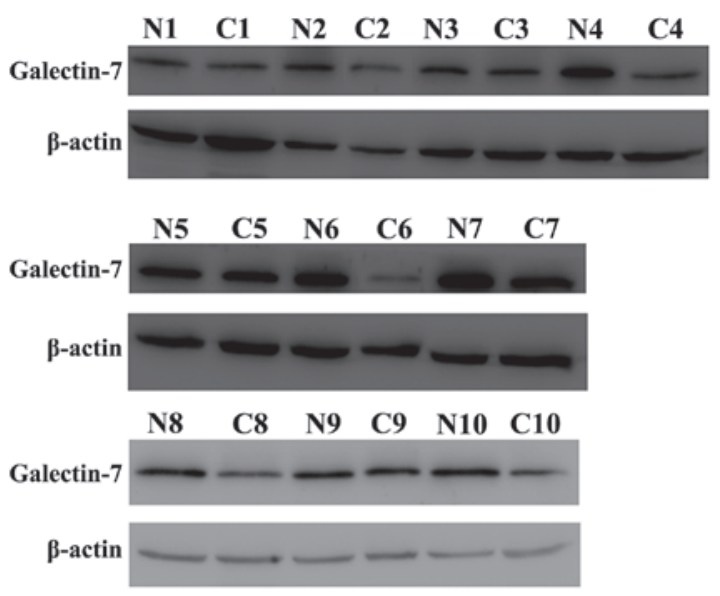

B

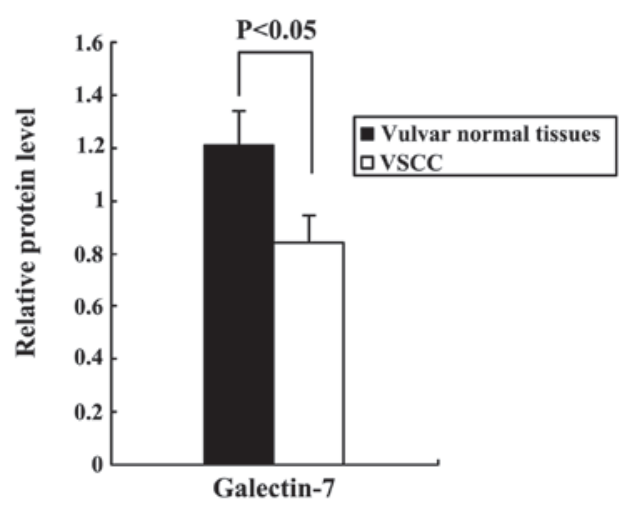

Figure 1. Downregulation of Gal-7 in VSCC tissues. (A) Expression of Gal-7 in 10 pairs of VSCC (C1-C10) and normal vulvar tissues (N1-N10); $\beta$-actin was used as an internal standard. (B) Gal-7 was significantly downregulated in the VSCC samples relative to the normal vulvar tissues $(\mathrm{P}<0.05)$. VSCC samples $\mathrm{C} 1$ and $\mathrm{C} 10$ exhibited stage I disease, samples $\mathrm{C} 3, \mathrm{C} 5, \mathrm{C} 7$ and $\mathrm{C} 9$ exhibited stage II disease, and samples C2, C4, C6 and C8 exhibited stage III disease. Gal-7, Galectin-7; VSCC, vulvar squamous cell carcinoma.

in IHC between groups, to permit correlation with clinicopathological characteristics. The correlation between two variables in the MSP test was evaluated using Pearson's $\chi^{2}$ test. $\mathrm{P}<0.05$ was considered to indicate a statistically significant difference.

\section{Results}

Gal-7 protein expression. Western blot analysis of total protein in the VSCC tissues and normal vulvar tissues confirmed that Gal-7 expression was significantly downregulated in VSCC relative to normal vulvar tissues $(\mathrm{P}<0.05$; Fig. 1 , with $\beta$-actin used as a loading control). The expression and localization of Gal-7 was examined by IHC in tissue samples from 50 cases of VSCC and 20 normal vulvar biopsies. Cytoplasmic and nuclear staining was observed in the epithelial layers of all 20 samples of normal vulvar tissue. Cytoplasmic staining was observed in the cancer nests of 50 cases of VSCC. Statistical analysis indicated that Gal-7 expression was significantly downregulated in the VSCC tissues compared with the normal vulvar tissues $(\mathrm{P}<0.05$; Fig. 2; Table I).

Next, the study investigated the potential correlation between Gal-7 expression and clinicopathological factors in patients with VSCC (Table II). The age of the patients did not differ 

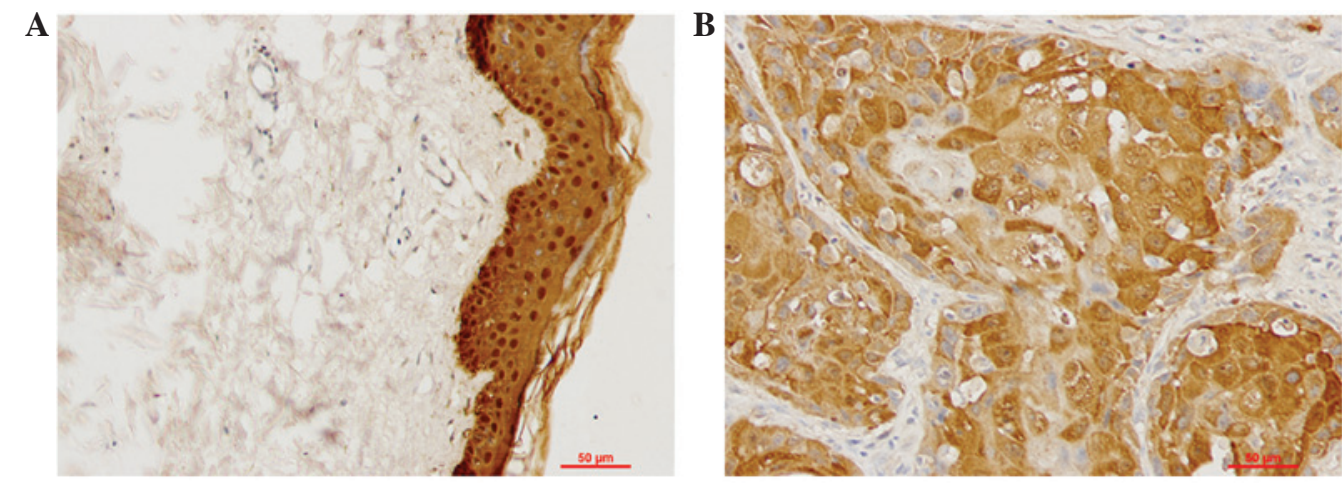

Figure 2. Representative immunohistochemical staining images of Galectin-7 in (A) normal vulvar tissue and (B) vulvar squamous cell carcinoma (magnification, $\mathrm{x} 200)$.

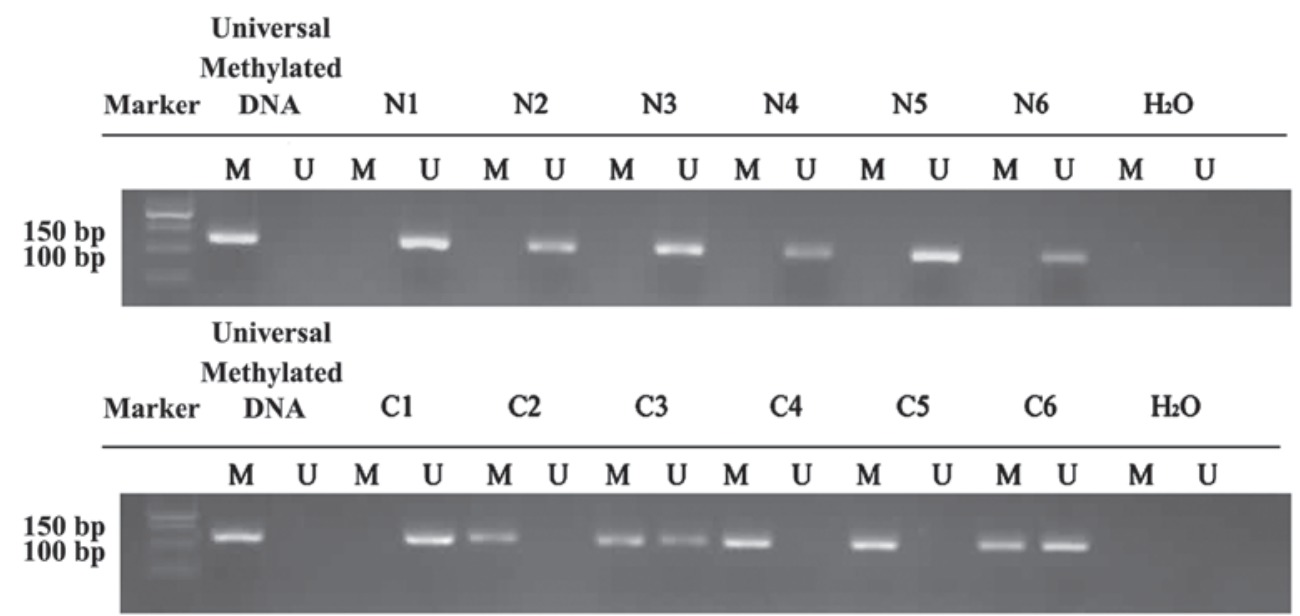

Figure 3. Methylation-specific polymerase chain reaction analysis of the Galectin-7 gene promoter in 6 vulvar squamous cell carcinoma samples (C1-6) and 6 normal vulvar tissues (N1-6). The methylated (M) and unmethylated (U) DNA was amplified using primers specific for each methylation status. Universal methylated DNA was used as a positive loading control and distilled water was used as a negative control.

significantly between the two groups. Gal-7 expression was significantly lower in the patients with stage II and III disease compared with the patients with stage I disease. Gal-7 expression was also significantly lower in the patients with a well-differentiated tumor histology compared with those patients who presented with moderately- and poorly-differentiated malignancies, and was similarly reduced in patients with lymph node metastases. Together, these findings describe a correlation between downregulated Gal-7 expression and advanced clinical stage, poor tumor differentiation and regional lymph node metastasis.

DNA hypermethylation in the promoter of the Gal-7 gene in VSCC. The degree of methylation at the Gal-7 promoter was significantly lower in the normal vulvar tissues compared with the VSCC samples ( $\mathrm{P}=0.023$; Fig. 3 ). In the 20 normal vulvar tissues, methylation was found at $30 \%$ of $\mathrm{CpG}$ bases, compared with $60 \%$ in the $30 \mathrm{VSCC}$ samples.

The correlation between Gal-7 gene promoter methylation and clinicopathological factors in the patients with VSCC was also examined (Table II). Increased Gal-7 promoter methylation was correlated with advanced clinical stage, poor tumor differentiation and regional lymph node metastasis $(\mathrm{P}<0.05)$. There was no association between patient age and Gal-7 promoter methylation.

\section{Discussion}

Gal-7 is an important member of the galectin family that is mainly expressed in stratified epithelia, particularly in the epidermis, and also in various types of cancer. Gal-7 is associated with the differentiation and maturation of epithelial tissue, and with the regeneration process of damaged skin tissue (13). The biological functions of Gal-7 are diverse and include the regulation of cell growth, cell adhesion and apoptosis (14-16).

In recent years, numerous studies have shown that Gal-7 plays an important role in tumorigenesis, although the mechanisms underlying this remain under debate. Overexpression of Gal-7 has been reported in several tumors, including pancreatic cancer, esophageal squamous cell carcinoma, buccal squamous cell carcinoma, and hypopharyngeal and laryngeal squamous cell carcinoma $(7,8,17,18)$. Park et al (19) reported that Gal-7 induces the expression of matrix metalloproteinase-9 (MMP-9) through the p38 mitogen-activated protein kinase signaling pathway, promoting tumor metastasis in human cervical adenocarcinoma. Saussez et al (18) also found that the overexpression of Gal-7 could induce the expression of MMP-9 in hypopharyngeal and laryngeal squamous cell carcinoma. Downregulation of Gal-7 in ovarian 
Table III. Clinicopathological features of Galectin-7 gene promoter hypermethylation.

\begin{tabular}{|c|c|c|c|c|}
\hline Variable & $\mathrm{n}(\%)$ & Methylated & Unmethylated & P-value \\
\hline Total & $30(100.0)$ & 18 & 12 & \\
\hline Age, years & & & & 0.866 \\
\hline$\leq 45$ & $8(26.7)$ & 5 & 3 & \\
\hline$>45$ & $22(73.3)$ & 13 & 9 & \\
\hline Lymph node metastasis & & & & 0.034 \\
\hline Negative & $21(70.0)$ & 10 & 11 & \\
\hline Positive & $9(30.0)$ & 8 & 1 & \\
\hline Clinical stage & & & & 0.006 \\
\hline I & $9(30.0)$ & 2 & 7 & \\
\hline II and III & $21(70.0)$ & 16 & 5 & \\
\hline Histological type & & & & 0.016 \\
\hline Well-differentiated & $17(56.7)$ & 7 & 10 & \\
\hline Moderately- and poorly-differentiated & $13(43.3)$ & 11 & 2 & \\
\hline
\end{tabular}

cancer cell lines using small interfering RNA results in the inhibition of ovarian cancer cell proliferation (20), suggesting that the overexpression of Gal-7 in these tumors may promote proliferation and metastasis. By contrast, the underexpression of Gal-7 has also been reported in several tumors, including gastric cancer and neuroblastoma (15,21). Kim et al (21) treated gastric cancer cell lines using the demethylating agent, 5-azacytidine, with a resulting marked increase in Gal-7 expression, suggesting that Gal-7 expression is regulated by DNA methylation in gastric cancer cell lines. Kopitz et al (15) reported that Gal-7 acts as a lectin on the cell surface, and that it could inhibit proliferation by binding to ganglioside GM1 on the surface of neuroblastoma cells.

Gal-7 is also able to act as a pro-apoptotic protein that is induced by $\mathrm{p} 53$. The induction of apoptosis by Gal-7 is believed to involve c-Jun $\mathrm{N}$-terminal kinase activation, release of mitochondrial cytochrome $c$ and B cell lymphoma-2 binding in the mitochondrial membrane (14,22-24). Ectopic expression of Gal-7 in cancer cells increases their susceptibility to apoptosis and thereby suppresses tumor growth (25). In addition, Gal-7 has also been described as enhancing immune function, with the study by Rossi et al (26) finding that Gal-7 single glycosylation recognition sites could bind to the $\alpha \beta$ T-cell antigen receptor-cluster of differentiation 3 complex on the surface of T lymphocytes, suggesting a role in T-cell activation and proliferation. Menkhorst et al (16) reported that pre-treatment of trophoblasts with soluble Gal-7 enhanced adhesion to endometrial epithelial cells, indicating a potential role in embryo attachment to endometrial cells and perhaps a more general function in cell adhesion.

It is therefore clear that Gal-7 has diverse cellular roles. In agreement with this, the present results showed that the expression of Gal-7 was lower in VSCC samples compared with normal vulvar tissues, with downregulation of Gal-7 correlating with advanced clinical stage, poor differentiation and lymph node metastasis in VSCC. As such, Gal-7 downregulation can be observed to have a deleterious effect in VSCC.
The expression of certain members of the galectin family has been demonstrated to be under the control of epigenetic regulatory mechanisms $(11,12)$. It is unclear whether Gal-7 expression in VSCC is similarly controlled. Kim et al (21) reported that the expression of Gal-7 was downregulated in gastric cancer, and that this was the consequence of alterations in DNA methylation status. Demers et al (27) and Moisan et al (28) found that treatment of T lymphoma cell lines with 5-aza-2'-deoxycytidine was sufficient to induce Gal-7 expression, although these cells do not express Gal-7 under normal conditions. We hypothesized that the methylation status of the Gal-7 gene could be clinically relevant in determining its expression in VSCC, with promoter $\mathrm{CpG}$ methylation inhibiting transcription of the Gal-7 gene and demethylation resulting in an increase in its expression. Thus, the Gal-7 gene promoter methylation status was analyzed in the VSCC tissues and normal vulvar tissues by MSP. The results showed that the Gal-7 gene promoter in the VSCC tissues was significantly more likely to be methylated compared with that in the normal vulvar tissues; an observation that is consistent with the lower Gal-7 expression in VSCC samples compared with normal controls. The present data also revealed significantly more Gal-7 promoter methylation in cases with poor differentiation, advanced clinical stage and lymph node metastasis. Thus, the malignant potential of cells was associated with Gal-7 gene promoter methylation. This is of particular relevance in the development of novel therapeutic approaches to this condition, and suggests that the demethylation of the Gal-7 gene promoter may be of benefit in reducing the development of VSCC.

We anticipate that these findings will provide a logical basis for the design and development of further studies examining demethylation in VSCC.

\section{Acknowledgements}

This study was supported by a grant from the National Natural Science Foundation of China (no. 30973190). 


\section{References}

1. Coulter J and Gleeson N: Local and regional recurrence of vulvar cancer: Management dilemmas. Best Pract Res Clin Obstet Gynaecol 17: 663-681, 2003.

2. Liu FT and Rabinovich GA: Galectins as modulators of tumour progression. Nat Rev Cancer 5: 29-41, 2005.

3. Magnaldo T, Fowlis D and Darmon M: Galectin-7, a marker of all types of stratified epithelia. Differentiation 63: 159-168, 1998

4. Yang RY and Liu FT: Galectins in cell growth and apoptosis. Cell Mol Life Sci 60: 267-276, 2003.

5. Zhu H, Wu TC, Chen WQ, Zhou LJ, Wu Y, Zeng L and Pei HP: Roles of galectin-7 and S100A9 in cervical squamous carcinoma: Clinicopathological and in vitro evidence. Int J Cancer 132: 1051-1059, 2013.

6. Rorive S, Eddafali B, Fernandez S, Decaestecker C, André S, Kaltner H, Kuwabara I, Liu FT, Gabius HJ, Kiss R and Salmon I: Changes in galectin-7 and cytokeratin-19 expression during the progression of malignancy in thyroid tumors: Diagnostic and biological implications. Mod Pathol 15: 1294-1301, 2002.

7. Takata T, Ishigaki Y, Shimasaki T, Tsuchida H, Motoo Y, Hayashi A and Tomosugi N: Characterization of proteins secreted by pancreatic cancer cells with anticancer drug treatment in vitro. Oncol Rep 28: 1968-1976, 2012.

8. Zhu X, Ding M, Yu ML, Feng MX, Tan LJ and Zhao FK: Identification of galectin-7 as a potential biomarker for esophageal squamous cell carcinoma by proteomic analysis. BMC Cancer 10: 290, 2010

9. Ohno T, Nakano T, Niibe Y, Tsujii H and Oka K: Bax protein expression correlates with radiation-induced apoptosis in radiation therapy for cervical carcinoma. Cancer 83: 103-110, 1998.

10. Polyak K, Xia Y, Zweier JL, Kinzler KW and Vogelstein B: A model for p53-induced apoptosis. Nature 389: 300-305, 1997.

11. Benvenuto G, Carpentieri ML, Salvatore P, Cindolo L, Bruni CB and Chiariotti L: Cell-specific transcriptional regulation and reactivation of galectin-1 gene expression are controlled by DNA methylation of the promoter region. Mol Cell Biol 16: 2736-2743, 1996.

12. Ruebel KH, Jin L, Qian X, Scheithauer BW, Kovacs K, Nakamura N, Zhang H, Raz A and Lloyd RV: Effects of DNA methylation on galectin-3 expression in pituitary tumors. Cancer Res 65: 1136-1140, 2005

13. Gendronaneau G, Sidhu SS, Delacour D, Dang T, Calonne C, Houzelstein D, Magnaldo T and Poirier F: Galectin-7 in the control of epidermal homeostasis after injury. J Mol Biol Cell 19: 5541-5549, 2008

14. Bernerd F, Sarasin A and Maagnaldo T: Galectin-7 overexpression is associated with the apoptotic process in UVB-induced sunburn keratinocaytes. Proc Natl Acad Sci USA 96: 11329-11334, 1999.

15. Kopitz J, André S, von Reitzenstein C, Versluis K, Kaltner H, Pieters RJ, Wasano K, Kuwabara I, Liu FT, Cantz M, et al: Homodimeric galectin-7 (p53-induced gene 1) is a negative growth regulator for human neuroblastoma cells. Oncogene 22 6277-6288, 2003.
16. Menkhorst EM, Gamage T, Cuman C, Kaitu'u-Lino TJ, Tong S and Dimitriadis E: Glectin-7 acts as an adhesion molecule during implantation and increased expression is associated with miscarriage. Placenta 35: 195-201, 2014.

17. Chen J, He QY, Yuen AP and Chiu JF: Proteomics of buccal squamous cell carcinoma: The involvement of multiple pathways in tumorigenesis. Proteomics 4: 2465-2475, 2004.

18. Saussez S, Decaestecker C, Lorfevre F, Chevalier D, Mortuaire G, Kaltner H, André S, Toubeau G, Gabius HJ and Leroy X: Increased expression and altered intracellular distribution of adhesion/growth-regulatory lectins galectins-1 and -7 during tumour progression in hypopharyngeal and laryngeal squamous cell carcinomas. Histopathology 52: 483-493, 2008.

19. Park JE, Chang WY and Choa M: Induction of matrix ametalloproteinase- 9 by galectin-7 through p38 MAPK signaaling in HeLa human cervical epithelial adenocarcinoma cells. Oncol Rep 22: 1373-1379, 2009.

20. Kim HJ, Jeon HK, Lee JK, Sung CO, Do IG, Choi CH, Kim TJ, Kim BG, Bae DS and Lee JW: Clinical significance of galectin-7 in epithelial ovarian cancer. Anticancer Res 33: 1555-1561, 2013.

21. Kim SJ, Hwang JA, Ro JY, Lee YS and Chun KH: Galectin-7 is epigenetically-regulated tumor suppressor in gastric cancer. Oncotarget 4: 1461-1471, 2013.

22. Kuwabara I, Kuwabara Y, Yang R, Schuler M, Green D, Zuraw B, Hsu D and Liu F: Galectin-7 (PIG1) exhibits pro-apoptotic function through JNK activation and mitochondrial cytochrome c release. J Biol Chem 277: 3487-3497, 2002.

23. Villeneuve C, Baricault L, Canelle L, Barboule N, Racca C, Monsarrat B, Magnaldo T and Larminat F: Mitochondrial proteomic approach reveals galectin-7 as a novel BCL-2 binding protein in human cells. Mol Biol Cell 22: 999-1013, 2011.

24. Barkan B, Cox AD and Kloog Y: Ras inhibition boosts galectin-7 at the expense of galectin-1 to sensitize cells to apoptosis Oncotarget 4: 256-268, 2013.

25. Ueda S, Kuwabara I and Liu FT: Suppression of tumor growth by galectin-7 gene transfer. Cancer Res 64: 5672-5676, 2004.

26. Rossi NE, Reiné J, Pineda-Lezamit M, Pulgar M, Meza NW, Swamy M, Risueno R, Schamel WW, Bonay P, Fernández-Malavé E and Regueiro JR: Differential antibody binding to the surface alphabetaTCR. CD3 complex of CD4+ and CD8+ T lymphocytes is conserved in mammals and associated with differential glycosylation. Int Immunol 20: 1247-1258, 2008.

27. Demers M, Couillard J, Giglia-Mari G, Magnaldo T and St-Pierre Y: Increased galectin-7 gene expression in lymphoma cells is under the control of DNA methylation. Biochem Biophys Res Commun 387: 425-429, 2009.

28. Moisan S, Demers M, Mercier J, Magnaldo T, Potworowski EF and St-Pierre Y: Upregulation of galectin-7 in murine lymphoma cells is associated with progression toward an aggressive phenotype. Leukemia 17: 751-759, 2003. 